\title{
Spreadsheets for Numerical Analysis: A conceptual tool
}

\author{
Ozlem Cezikturk \\ Ataturk Fac. of Ed., Dept. of Primary Math. Ed., Marmara University, Istanbul, Turkey
}

\begin{abstract}
Using spreadsheets for mathematics education is not a new idea. However, analysing student logical mistakes for preserving error types and conceptual decision making would be first to study. A class of students were given two home works in order for grading. They were told to carry on calculations via spreadsheets and give the homework exam with spreadsheet file. In H1, questions were on root finding and solution of simultaneous equations. In $\mathrm{H} 2$, questions were on line and curve approximations, interpolation, numerical integration and numerical differentiation. These files are analysed by content analysis of qualitative method. By this way, it is hypothesized that they would do similar errors regarding error types and their decision making would inform us about their conceptual learning.
\end{abstract}

Key words: spreadsheets, numerical analysis, conceptual tools

\section{Introduction}

Technology use in education results in rich learning environments with increased motivation and increased interest of the learners. It is argued that if computers are used with respect to right epistemological approaches than we can see changes in the learning processes and education environments [6].

Spreadsheet programs in market; Excel, Lotus 1-2-3, open office and star office appeared first in $1980 \mathrm{~s}$ in personal computers [5]. All these programs basically do the same thing which can be named as electronic table keeping. A modern spreadsheet is identified as a combination of a scientific calculator, a graphing package, and a database program [5]. First usage of spreadsheets in mathematics education was of Sutherland \& Rojaro in 1993([8], [14]). Spreadsheet programs enable entering data sets into computers, listing data, searching for data blocks in a database and establishing new data from relationships of these data. Each cell in a spreadsheet contains values, formulas and functions. Functions may be like mathematical or logical operations that act on the values of the different cells and they are pre-made [5]. They consist multiple representations in the form of geometrical, numerical and algebraic [5]. Formulas are user-made and they require knowledge of spreadsheet but also the mathematics topic behind.

A spreadsheet environment can include many spreadsheets hence works as a file directory. A spreadsheet looks like a calculation notebook divided by rows and columns. The good thing about these programs is they carry calculations by themselves by only a formula typed in a cell. Adding more data, operating with them or changing them is not a problem. One of the best things about a spreadsheet program is repeated calculations. By only moving cursor under a list of cells, calculation within a cell is carried over. These calculations are problematic if done by

Corresponding author: Address: Ataturk Faculty of Education, Department of primary Mathematics

Education, Marmara University, Istanbul, TURKEY. E-mail address: ozlem.cezikturk@marmara.edu.tr,

Phone: +905377653970 Doi: 10.33793/acperpro.02.01.12 
hand. Spreadsheets give immediate feedback also. If there is a syntax problem within the cell, one can get immediate resolution [5]. If done with students, we can expect more discoveries from students as well [6]. Patterns are identified and listed and relations are revealed by a change in a parameter or a variable. These take so much time if tried in a classroom environment. Problem solving can be a result of spreadsheet programs as well. Students plan a problem solution ahead of time, can see their errors, and can control their solutions via spreadsheets ([8], [5]). A problem would not be thought as solved if not understood of its whys and how's. In short, spreadsheets help students to raise from problem solution detaching from problem solution finding ([1], [8], [5], [4]).

It is demonstrated that there appears higher motivation towards discovery of mathematical relationships finding via computer supported mathematics education. It is pointed to the instruction of abstract mathematics and its difficulty, hence proposes usage of spreadsheet in mathematics education via relations in rows and columns ([8], [11]). Literature also point to the positive effect of spreadsheets on conceptual learning [8]. It is important to note the abstract reasoning required from learners in building spreadsheets [5]. In some way, learner makes the primitive case of programming without any knowledge of software programming. In numeric analysis for example, by visualizing the error reduction of a method, error concept can be understood much better than hands on calculations. Fill-down function of spreadsheets helps to express recurrence relations [5]. One can store, present and calculate information [5].

Numerical analysis is full of these calculations, hence a good place to experiment on (Figure $1)$.

\begin{tabular}{|c|c|c|c|c|c|}
\hline \multicolumn{6}{|l|}{ 1. soru } \\
\hline $\mathrm{i}$ & $x i$ & yi & xiyi & xi2 & (yi-orty)2 yi-a0-a1xi \\
\hline 1 & 1,25 & 10,82 & \multicolumn{3}{|c|}{$13,5251,562523,851011,609845$} \\
\hline 2 & 2,53 & 8,53 & 21,5809 & \multicolumn{2}{|c|}{$6,40096,727539$} \\
\hline \multicolumn{6}{|c|}{0,32298} \\
\hline 3 & 3,24 & 6,35 & \multicolumn{3}{|c|}{$20,57410,49760,171189-1,30059$} \\
\hline 4 & 5,16 & 5,27 & 27,1932 & \multicolumn{2}{|c|}{$26,62560,443889-0,87589$} \\
\hline 5 & 5,82 & 4,12 & 23,9784 & \multicolumn{2}{|c|}{$33,87243,298764-1,50865$} \\
\hline 6 & 7,1 & 4,05 & $28,755 \quad 50,41 \quad 3,557939-0,57551$ & \multicolumn{2}{|c|}{$3,557939-0,57551$} \\
\hline 7 & 8,07 & 6,2 & \multicolumn{3}{|c|}{$50,03465,12490,0695642,334676$} \\
\hline 8 & \multicolumn{5}{|c|}{$10,252,1522,0375105,062514,33569-0,00686$ toplam } \\
\hline \multicolumn{6}{|c|}{43,42 47,49 207,678 299,5564 52,45559 -4E-15 } \\
\hline \multicolumn{6}{|c|}{ ortalama $\quad 5,4275 \quad 5,93625$} \\
\hline \multicolumn{6}{|c|}{$\mathrm{a} 1=\left(8^{*} \mathrm{~d} 13-\mathrm{b} 13^{*} \mathrm{c} 13\right) /\left(8^{*} \mathrm{e} 13-\mathrm{b} 13 * \mathrm{~b} 13\right)$} \\
\hline$-0,7837$ & sy $/ x=$ & \#SAYI! & $0 \mathrm{a} 0=\mathrm{c} 14-\left(\mathrm{a} 17^{*}\right.$ & *b14) & \\
\hline 10,18978 & & $y=10$ & $18978+(-0,7837$ & & \\
\hline
\end{tabular}

Figure 1. Solution of first problem in $\mathrm{H} 1$ 


\subsection{Literature on spreadsheets use in mathematics education}

It is indicated that to teach "variability" concept by spreadsheets result in comprehension of the concept and reasoning towards this concept easily [16]. In a teaching experiment, the mathematical topic was patterns and relations and the level was $6^{\text {th }}$ grade. Some studies searched for using spreadsheets in case of problem solving and found more positive attitudes towards mathematics, even if not significant [13]. Their problem solving achievements were higher, and positive attitudes towards problem solving flourished as a result.

Computer technology has developed in parallel to the numerical analysis methods. We can find the best examples to this as carrying operations and changing them in seconds. Disadvantage is; formulas in the cells are not easily seen as cell value. Somebody would need to point the cursor to that cell to see what is inside. Theory of finite elements was existent in 1930s but it was so hard to put in action by hand, it waited till the development of spreadsheet technology. There is no need for expensive programs and no excuse of not knowing computer programming. Some investigated preservice teachers' function graphics drawing after instruction with spreadsheets [3]. They argued that in concretizing knowledge, in increasing achievement, increasing positive attitudes and motivation, and even in achieving self-confidence, spreadsheets can be helpful. The study included 136 preservice math teacher who was taking general mathematics II course. Especially drawing graphics of $2^{\text {nd }}$ order and $3^{\text {rd }}$ order functions, difficulties could be lessened as they insisted. The study was a pre-test post-test control group quasi experimental study.

Results also showed that visualization is a helper in understanding functions of higher order. Some example problems which work best in spreadsheets are as follows:

- In a money box, there are 100.000.000, 500.000, 250.000, 100.000, 50.000, 25.000, $10.000,5.000,1.000,500$ paper moneys. If the money total is 17.178 .500 , what is the counts of each money? [8]

- $\quad$ From 1 to 9, each number will be written once, in a 3 digit numbers under a rule. The rule is such that first to second is $1 / 2$, first to third is $1 / 3$, hence find these numbers [8].

- We can find $\sqrt{78}$ by bringing $6 \times 13$ rectangle to a square and hence we can say that the result should be in between 8 and 9 [6].

Some studied preservice mathematics teachers' views on computer supported mathematics instruction by 73 preservice teachers [18]. Their study showed that interest towards computers was in medium level. They believe; 1984 companion of having all schools excess to computers was a good start. But not as expected. They have seen difference in boys' interest in computers more than girls and successful students' more than unsuccessful ones. There are some negative studies as of [10]. She found that traditional mathematics education produces more success than spreadsheet based mathematics education. Also, mathematics self-efficacy level and computer self-efficacy level are highly related. Mathematics achievement and computer self-efficacy level are also highly related.

There are numerous studies on how spreadsheets can improve business efficacy and also lowers work load of workers and increase the business productivity of workers like [12]. Spreadsheets 
are even used for risk analysis and decision making in business topics. Some stressed the importance of sample case use, mathematical modelling, software, interactive and active instructional methods in business education [17]. Objective and conscious decision making processes are a must in numerical methods [17]. Especially in decision making as of which method to choose to find the roots of a third or fourth order equation or, identifying the solution of a system of equations, error analysis could be a threshold.

\subsection{Error analysis and decision making}

Error types in numerical analysis can be listed as modelling, measurement and numerical mistakes ([7], [15]). By modelling mistakes, we refer to choosing the wrong method to carry out the calculations needed. For example, Newton-Raphson method for finding the roots of an equation may give the result in less steps than other methods such as finding the middle point method or the wrong-position method. All three methods give the same resultant root but one is in less steps and if the time is a problem, than one would choose Newton-Raphson method over the others. Measurement errors are based on measurement mistakes. Numerical errors are two type: 1) cut-off error, 2) rounding errors. Using 0, 33 instead of 0,3333333333 would result in rounding error however, cut off error would come out in using the series approximation of $\sin (\mathrm{x})$ and cutting off in small steps.

Errors in numerical analysis are two type: absolute error, and relative error. In absolute error $\left(e_{m}=\mid f(x)\right.$ analytical $-f(x)$ numerical $\mid$ while relative error is $e b=\mid((f(x)$ analytical- $f(x)$ numerical $) / f(x)$ analytical $) \mid$.

Regarding the content of numerical analysis, it is hypothesized that using spreadsheets may give more information on conceptual learning than any other technique. For this aim, a study was carried with a group of 22 students in a numerical analysis course of secondary preservice mathematics teachers. Their grades were given by two home works that they were supposed to carry on spreadsheets.

\section{Methodology}

In this study, research methodology is content analysis from qualitative research methods. Students' answers from two home works ( $\mathrm{H} 1 \& \mathrm{H} 2)$ on numerical analysis with spreadsheets were analysed for conceptual errors, conceptual mistakes, and misunderstandings. In H1, answers to five questions on numerical analysis on spreadsheets were collected. They were 22 pre-service secondary school mathematics education students and were taking numerical analysis course. The questions were given as mid-exam in the semester. They were asked to use spreadsheets. They take courses on computers and office programs, hence they were thought to be spreadsheet literate. Though, they were given a miniature course on spreadsheet usage and tricks.

- $F(x)=x^{2}+6 x-7(x=1, x=-7)$ find root by middle point method, wrong position method and Newton-Raphson method (take $\times 1=-10, x 2=0$ ) Detech errors and compare them.(H1)

- $\quad x_{1}=2, x_{2}=-3, x_{3}=5, x_{4}=1$

$0,7 x_{1}+0,17 x_{2}-3 x_{3}-x_{4}=-15,11$

$0,2 x_{1}-0,4 x_{2}+2,1 x_{3}-x_{4}=11,1$ 


\section{$1,3 x_{1}+2,1 x_{2}-1,8 x_{3}+x_{4}=-11,7$ \\ $-5,2 x_{1}-x_{2}-x_{3}+4 x_{4}=-8,4$ solve the system by Gaussian Elimination method and Gauss-Jordan method. Detech errors, build a report and compare. (H1)}

They were taught all these numerical methods in the course. Especially decision making upon data is discussed in the class with specific examples. To understand if they have used right formulas and ways for numerical methods, they were told that they would give their spreadsheet files as exam answers. By this content validity can be achieved. Construct validity is achieved by using not any textbook data but only data specifically designed for this exam. Reliability can be achieved via question choice since first question uses three methods for root finding and second question uses two methods for simultaneous systems of equations. Answers were pregiven so that they could check and correct their mistakes if any.

In $\mathrm{H} 2$; two questions were on linear approximation and curve approximation, 3 questions were on different interpolations, and last questions were on numerical integral and numerical differentiation. Here questions were not given in this paper since it is believed that they were already passed through the initiation phase of spreadsheets in numerical analysis.

\subsection{Data Analysis}

Excel sheets and files students sent was saved under a directory named "Numerical". Each data file was checked for different type of errors they made: modelling and numerical. Since they did not carry any measurements, this type of error can be cancelled from analysis. These two type of errors will be classified for emerging lists. Errors were analysed in two dimensions: first within a student's file and within same questions. It was hypothesized that similar kind of errors would come out of each students' file and from each question. Themes were detected. They were also asked for spreadsheet use in numerical analysis in general in whole group discussion. It was also hypothesized that there would be modelling errors which could be decided from their decision making on which model to choose. By content analysis of errors and decision analysis numerical methods via spreadsheets can flourish whereas by mistakes in cell values and formulas in cells both understanding of numerical methods and understanding of the spreadsheet use in order.

\section{Results and Discussion}

Students were not given a hint about relative and absolute cell values, but if they used spreadsheet tutorials, they certainly would use some in need. By its usage, the concept of variable and parameter would come to the surface. As different from other mathematics areas, in numerical analysis formulas include many variables and many constants at the same time. Only two did have some problems in these from H1. It is a pretty good result. In H2, there were not specific problems with this issue but they did have some problems in finding values of functions they formulated. It is hoped, by this research numerical analysis course professors would be informed about possible uses of spreadsheets for conceptual learning of numerical analysis methods without any knowledge of programming languages. 
5 out of 22 students had problems with detecting right locations for values to use in formulas in H1. Some had problems with writing the right formula for spreadsheet and they used the results somebody else did and found. It was understood with missing formulas in cells. 3 out of 22 gave no formulas. Some gave the same formulas their successful friends did (6/22). It is a man's way of taking what is safe and using it. Hence, it is understandable but they did have some mistakes due to source being incorrect (6/22).

Problems with locations may due to spreadsheet usage ability but it may also due to having problems with numerical analysis formulas. Some formulas change in each step as in interpolation. Even though these home works were carried as homework, and hence notebooks and books were open, since data is author made and not from a book, they would need to understand the formulas and their basic usage up to the last variable in them. For example, in Gauss Jordan, they were needed to carry out different formula yet they tend to took the results of Gauss elimination method and continued from it since it resembled to it (5/22). Some students did not understand all they made hence they did not give any report (9/22). Look that this ratio is nearly half of the class. From these, 2 ran away from giving reports for not understood problems. Some did have problems with the syntax of the spreadsheets. As of 3/22, one did have forgotten a parenthesis, one did have problem with variable/constant notation, one did have problem with formula writing, etc. Only $3 / 22$ students were out of wrong answers. This is pretty low since the ratio is nearly $10 \%$. With open books and a wider time interval, they should have had a much higher ratio of success. It was the professors' first time of teaching numerical analysis, students were not ready for a spreadsheet use, and it would be preferable to use spreadsheets in the class as well even though the results were taken from spreadsheets programs as in table format. $2 / 22$ students were having unique problems as showing not understood error reduction. Since, if the error reduction was right enough, in each step, it is assumed that the error would decrease, but in these students' answers, error measure was in a cyclic manner and holding "turning backs" to bigger error measure. They were supposed to identify this problem and change the reference point or the variable in each step accordingly or the model if necessary but they did not.

In $\mathrm{H} 2$, they were graded on 7 question since there were problems with the question. The most interesting conceptual mistake was on linear interpolation. After searching for 1 and 6 as $\mathrm{x}_{\mathrm{i}} \mathrm{s}$, they were supposed to give 2 and 6 for new $\mathrm{x}_{\mathrm{i}} \mathrm{S}$ since their required number $(3,27)$ was in between these two numbers. Instead they mostly (17/22) used 1 and 2 (figure 2) and hence their error measure was high. Even after the first experience with spreadsheets in H1, some did have formula problems in H2(2/22). They did take the square but put the parenthesis in the wrong place. Some did have problems with numerical integration and this resulted them in finding second derivative to find integral (4/22) (Figure 3). This course is a 3rd year course on the program and they already took many courses on calculus. Hence, it is not easy to understand how they made such a mistake. Most did have problems on finding analytical results for numerical integral $(6 / 22)$.

In some answer sheets some lines of data were missing, this may be due to copy paste problems (4/22). Only one student was having problems with not matching data line. There may be a problem with copy paste of a value, hence relocation of a variable in a formula. Ins spite of the fact the it was not asked, some did draw the graphs of line and curve approximations $(2 / 22)$. 
Some did have conceptual breakthrough with line and curve approximations. Even though the numbers did show a relationship, they did mention that the data were not suitable for a line approximation etc. This may show that there was a problem with understanding the concept of approximation to a line of a $x-y$ relationship. This problem can be seen in a graph of a student in figure 4.

\begin{tabular}{|lllll|}
\hline 3. soru & & & & \\
$x 0=1$ & $x 1=6$ & ise & $f 1(3,27)=0,813457$ hata & $0,31342331,34 \%$ \\
$x 0=2$ & $x 1=6$ & ise & $f 1(3,27)=1,041955$ & $0,12056512,05 \%$ \\
\hline
\end{tabular}

Figure 2. Answer to question 3 of $\mathrm{H} 2$.

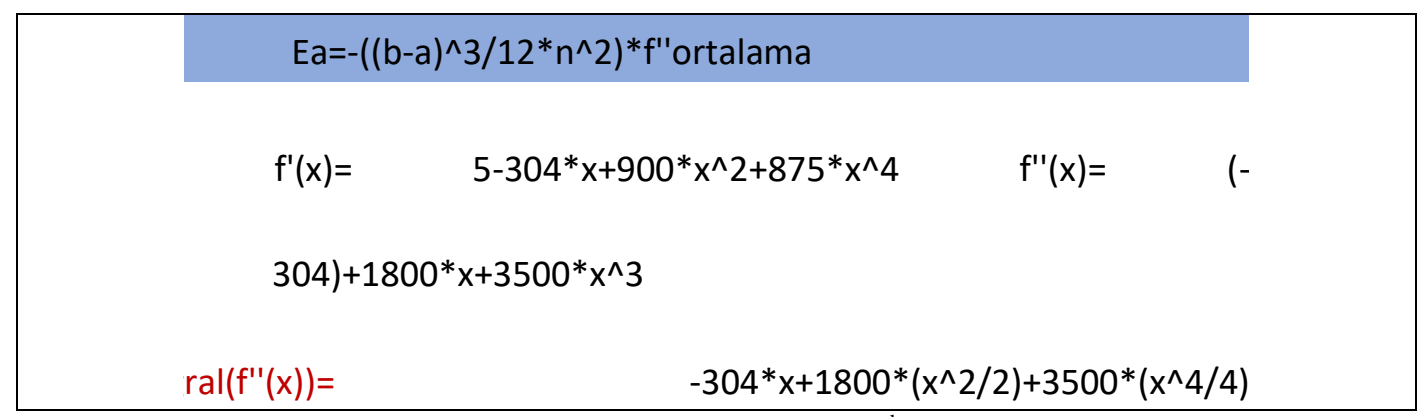

Figure 3. Students' answers to numerical integration as taking $2^{\text {nd }}$ derivative first and taking integral then.

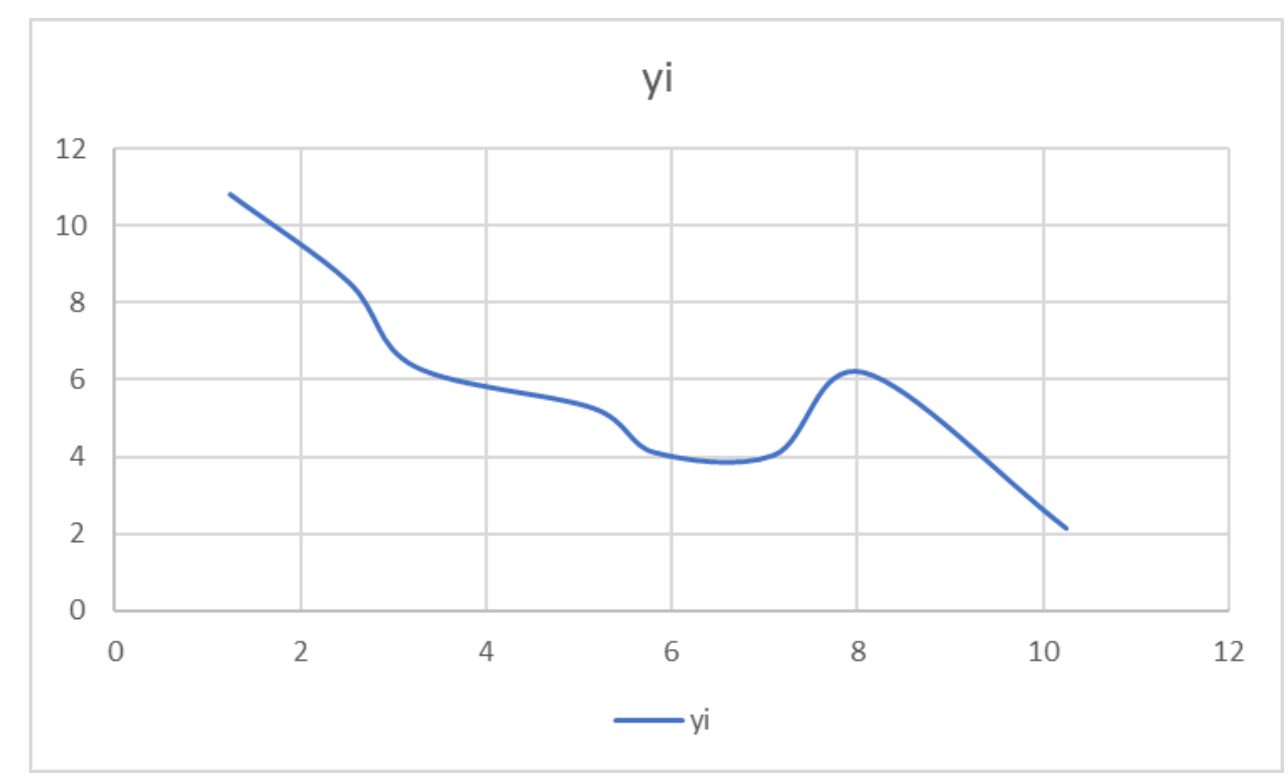

Figure 4. One students' answer to a line approximation in $\mathrm{H} 2$.

Some did give the formula as a string to show the formula, if they believed in heart that it was true. Even if spreadsheets are great ways to carry no miscalculations, some did have calculation errors: 3 /22 students had calculation mistakes. These may be due to wrong values, wrong formulas, or wrong parenthesis usage.

$\mathrm{f} 2(\mathrm{x})=[((\mathrm{x}-\mathrm{x} 1) /(\mathrm{x} 0-\mathrm{x} 1) *(\mathrm{x}-\mathrm{x} 2) /(\mathrm{x} 0-\mathrm{x} 2)) * \mathrm{f}(\mathrm{x} 0)]+[((\mathrm{x}-\mathrm{x} 0) /(\mathrm{x} 1-\mathrm{x} 0) *(\mathrm{x}-\mathrm{x} 2) /(\mathrm{x} 1-\mathrm{x} 2)) * \mathrm{f}(\mathrm{x} 1)]+[((\mathrm{x}-\mathrm{x} 0) /(\mathrm{x} 2-\mathrm{x} 0) *(\mathrm{x}-\mathrm{x} 1) /(\mathrm{x} 2-\mathrm{x} 1)] * \mathrm{f}(\mathrm{x} 2)$ 
Figure 5. $2^{\text {nd }}$ degree lagrange interpolation formula froma students' spreadsheet as string next to its value.

\section{Conclusions}

Spreadsheets should be used in especially numerical analysis like math topics. Students should be given some free time to work and get used to them. It is a pity if they graduate without using a spreadsheet properly. Spreadsheets are right, coherent, and free of calculation errors but students are not. They still would carry some miscalculation and especially if they had problems with constant and variable notation in a spreadsheet. They would have problems with conceptual understanding of the formulas, and these mistakes show themselves in coherence like graphical /algebraic, algebraic/symbolic, or graphical/symbolic representations and how they are connected.

When they are asked if they would like to use spreadsheets again, they chose H2 with spreadsheets to carry on since topics like numerical analysis carry many decimal numbers related with intriguing formulas and hence it is much easier to see the calculation or formula mistakes right away without a much hustle. They mentioned that they feel like they are accountant. And they are in control of the numbers they are dealing with. But still, they need to study hard to understand the conceptual framework well before and whilst using a spreadsheet on numerical analysis since the numbers would mean nothing by themselves. That would be interesting to search for if they have some degree of numerical ability by a measure as in [2]. And it would be good to see if the mistakes students make are due to any algebraic difficulties students have in general [9]

It would be very interesting to find any usage of conditional formatting within formulas as in [1]. Since, numerical methods use some conditional decisions based steps in especially two questions asked by the data collection instrument $\mathrm{H} 1$.

\section{References}

[1]Abramovich S, Sugden S. Spreadsheet conditional formatting. An untapped resource for mathematics education, Spreadsheets in Education (ejSiE), 1,2,3.,2004, Retrieved from https://www.researchgate.net/publication/27827005_Spreadsheet_Conditional_Formatting_A n_Untapped_Resource for_Mathematics_Education,

[2]Akkoyunlu B, Soylu Y, Çağlar M. Üniversite öğrencileri için "Sayısal Yetkinlik Ölçeği" geliştirme çalışması. Hacettepe Üniversitesi Eğitim Fakültesi Dergisi. 2010;39:10-19. [3]Aksoy NC, Çalık N, Çinar C. Excel ile matematik öğretiminin öğretmen adaylarının fonksiyon grafikleri çizimi üzerine etkisi, Uluslarası Eğitim Bilim Kongresi, 2012, retrieved from http://kongre.nigde.edu.tr/xufbmek/dosyalar/tam_metin/pdf/2504-30_05_201223_48_11.pdf [4]Alan MA, Yeşilyurt C. Doğrusal programlama problemlerinin excel ile çözümü, C. Ü. İktisadi ve İdari Bilimler Dergisi, 2004;5: 1: 151-162.

[5]Baker J, Sugden SJ.Spreadsheets in education-The first 25 years, Spreadsheets in Education(ejSiE), 2003:1:1:2; Retrieved from https://www.researchgate.net/publication/27827008_Spreadsheets_in_Education_-The_First $\underline{25 \text { Years }}$ 
[6]Baki A. Bilgisayar donanımlı ortamda matematik öğrenme, Hacettepe Üniversitesi Eğitim Fakültesi dergisi, 2000;19:186-193.

[7]Bayıroğlu H.Sayısal yöntemler ders notları [Numerical analysis course notes]. Yıldız

Üniversitesi. 2006; retrieved from http://www.yildiz.edu.tr/ hbayir/Sayisal_yontemler_kitabi.pdf

[8]Dede Y, Argun Z. Matematik öğretimi'nde elektronik tabloların kullanımı. Pamukkale Üniversitesi Eğitim Fakültesi Dergisi, 2003:2: 14: 113-131.

[9]Dettori G, Garuti R, Lemut E, Netchitailova L. An analysis of the relationship between spreadsheet and algebra, L. Burton and B. Jaworsky (Eds.) In Technology in mathematics teaching: a bridge between teaching and learning, retrieved from https://www.researchgate.net/publication/235887982. Lund: Chartwell, Bratt, 1995;pp.261274. ISBN 9144607113.

[10]Işıksal M. Elektronik tablolama ve dinamik geometri yazılımının 7. Sınıf öğrencilerinin matematik başarısı ve matematik öz yeterlik algısına etkisi [The Effect of spreadsheet and dynamic geometry software on the mathematics achievement and mathematics self-efficacy of 7th grade students], Thesis submitted to METU, Ankara,Turkey,2002.

[11]Kutluca T. Excel yazılımı ile geliştirilen bilgisayar destekli bir öğretim materyalinin tasarlanması [Constructing a computer- based teaching material by Excel language] , Electronic Journal of Education Sciences, 2013; 2:4: 40-49.

[12]Manavoğlu R. Hesap çizelgelerinde iş zekasına giriş [ Transition from spreadsheets to business intelligence], Thesis submitted to Bahçeşehir Üniversity, Istanbul, Turkey:2009.

[13]Meşe ÖF. Elektronik çizelge programlarının ilköğretim 7. Sınıf öğrencilerinin problem çözme başarılarına etkisi [Effect of spreadsheets on elementary school 7th grade students? problem solving achievements], 2010; thesis submitted to Ege Üniversity, İzmir, Turkey. [14]Soper JB, Lee MP. Computer spreadsheets for numerical analysis, International Journal of Mathematical Education in Science and Technology, 1994;25: 2: 245-253. DOI:

10.1080/0020739940250211.

[15]Sönmez M. Sayısal Analiz ders notları [Numerical Analysis Course Notes] 2008;retrieved from www.kocaelimakine.com/wp-content/uploads/2011/10/say1sal-analiz-ders notlar1mustafa-sönmez.pdf

[16]Turan P. Değişken kavramının öğretimi sürecinde elektronik tablo kullanımı: Bir öğretim deneyi [Using spreadsheets in teaching variable concept: A teaching experiment], Thesis submitted to Anadolu University, 2013.Eskişehir, Turkey.Anadolu Üniversitesi tez

[17]Yavuz VA. Sayısal yöntemler eğitiminin işletme öğrenimi açısından incelenmesi, S. Ü. İỉF Sosyal ve Ekonomik Araştırmalar Dergisi,2004; 171-188.

[18]Yenilmez K. Öğretmen adaylarının bilgisayar destekli matematik öğretimi dersine yönelik görüşleri, Manas Üniversitesi Sosyal Bilimler Dergisi, 2009;21:207-220. Retrieved from http://journals.manas.edu.kg/mjsr/oldarchives/Vol11_Issue21_2009/629-1698-1-PB.pdf 